\title{
Legal Status and Development Trends of Credit Unions in Polish Law and its Compliance with the WOCCU Standards and the International Cooperative Principles
} (Estado legal y tendencias de desarrollo de las cooperativas de ahorro y crédito en el derecho polaca y su cumplimiento de las normas WOCCU y los principios cooperativos internacionales)

\author{
Dominik Bierecki ${ }^{1}$ \\ National Association of Cooperative Savings and Credit Unions; \\ Cooperative Research Institute (Poland)
}

Summary: I. Introduction. II. Outline of historical development of credit unions' movement in Poland. III. Credit unions' legal status in Polish law. IV. The credit union as the European Cooperative Society and cross-border activity of the credit union. V. Conclusions. VI. References.

Sumario: I. Introducción. II Esquema del desarrollo histórico del movimiento de las cooperativas de ahorro y crédito en Polonia. III. Estatus legal de las cooperativas de ahorro y crédito en la legislación polaca. IV. La cooperativa de ahorro y crédito como la Sociedad Cooperativa Europea y la actividad transfronteriza de la cooperativa de ahorro y crédito. V. Conclusiones. VI. Referencias

\begin{abstract}
The article presents the outline of credit unions' history in Poland, the credit unions' legal status in Polish law and the credit union's legal status as the European Cooperative Society (SCE). Conclusions driven from this analysis are compared with the World Council of Credit Unions (WOCCU) standards and the contents of the International Cooperative Principles. Also, the article discusses legal environment, government attitude and development trends of credit unions' in Poland. In conclusion, the de lege ferenda postulates regarding credit unions' regulation in Poland are presented. Credit unions in Poland conduct not for profit business activity only with their members with
\end{abstract}

1 Dr. iur., attorney; National Association of Cooperative Savings and Credit Unions; Cooperative Research Institute; Sopot, Poland. Email: d.bierecki@krpj.pl. 
reservation to mediating in specific contracts on financial market which can be also conducted with nonmembers. Credit unions activity is subject to supervision of the Polish Financial Supervision Authority (FSA). Therefore credit unions regulation is characterized by duality of legal regime of private and administrative law. However, in certain fields of credit unions activity the FSA's supervision, performed under administrative legal regime, raises justified doubts in the light of the principle of cooperative autonomy as the FSA by law has the authority to impose specific orders and prohibitions on credit unions.

Keywords: cooperative enterprise, cooperatives supervision, credit unions, Poland.

Resumen: El artículo presenta el resumen de la historia de las cooperativas de ahorro y crédito en Polonia, el estado legal de las cooperativas de ahorro y crédito en la legislación polaca y el estado legal de las cooperativas de ahorro y crédito como la Sociedad Cooperativa Europea (SCE). Las conclusiones derivadas de estos análisis se comparan con los estándares del Consejo Mundial de Cooperativas de Ahorro y Crédito (WOCCU) y el contenido de los Principios Cooperativos Internacionales. Además, el artículo analiza el entorno legal, la actitud del gobierno y las tendencias de desarrollo de las cooperativas de ahorro y crédito en Polonia. Como conclusión, se presentan los postulados de lege ferenda sobre la regulación de las cooperativas de ahorro y crédito en Polonia. Las cooperativas de ahorro y crédito en Polonia realizan actividades comerciales sin fines de lucro solo con sus miembros con reserva para mediar en contratos específicos en el mercado financiero que también pueden llevarse a cabo con no miembros. La actividad de las cooperativas de crédito está sujeta a la supervisión de la Autoridad de Supervisión Financiera de Polonia (FSA). Por lo tanto, la regulación de las cooperativas de ahorro y crédito se caracteriza por la dualidad del régimen legal del derecho privado y administrativo. Sin embargo, en ciertos campos de actividad de las cooperativas de ahorro y crédito, la supervisión de la FSA, realizada bajo un régimen legal administrativo, plantea dudas justificadas sobre el principio de autonomía cooperativa, ya que la FSA tiene la autoridad de imponer órdenes y prohibiciones específicas a las cooperativas de de ahorro y crédito.

Palabras clave: empresa cooperativa, supervisión de cooperativas cooperativas de ahorro y crédito, Polonia. 


\section{Introduction}

The article considers the legal status of credit unions in Polish law. The article presents the outline of historical development of credit unions in Poland and the content of Polish credit unions' private law and public law regulation. The analysis considers conclusions on that matter in the light of the standards followed by the World Council of Credit Unions (WOCCU) ${ }^{2}$ and the International Cooperative Principles ${ }^{3}$. In the article the thesis is indicated that credit unions' regulation in Polish law is characterized by certain duality of private and public law regulation method.

2 Model Law for Credit Unions (2015, 4-80).

3 The pioneering event to shape the character of a cooperative was the establishment of the cooperative in Rochdale, England, in 1844, which foundation was based on seven principles, referred commonly as Rochdale Principles or International Cooperative Principles, recognized nowadays by the International Co-operative Alliance (ICA) as principles, which express the constitutive features of every cooperative. These principles are: 1) voluntary and open membership, 2) democratic member control, 3) member economic participation, 4) autonomy and independence, 5) education, training and information, 6) cooperation among cooperatives, 7) concern for community. The Rochdale Principles were adopted by the ICA in 1937 at a ICA Congress in Paris. Next they were modified in 1966 at a ICA Congress in Vienna and lastly in 1995 at a ICA Congress in Manchester, when they became part of the Declaration of Cooperative Identity (next to the definition of a cooperative and cooperative values). In 2012 the general assembly of the ICA approved guidelines for the practical application of the International Cooperative Principles in $21^{\text {st }}$ century societies. KURIMOTO et. al (2015, IX - XI). It should be noted that the International Cooperatives Principles are included in article 7 of the ICA Bylaws. INTERNATIONAL COOPERATIVE ALLIANCE (2019). However, the Rochdale Principles does not have a status of legal norms. They are not public or private international legal norms. Neither they constitute an international agreement. Because the Rochdale Principles are not legal norms the violation of these rules is not subject to any legal sanction. However, due to the Rochdale Principles, cooperatives are the only entrepreneurs in the world with agreed international operating principles. The Rochdale Principles should be considered as intra-organizational standards of the ICA. Lack of compliance with this standards may lead to exclusion of a member from the ICA.

It should be also recognized that organizations of cooperative character had been founded even before the foundation of Rochdale Pioneers' cooperative although from today's point of view we might say that those organizations lacked the characteristics of the cooperative. The first Greek cooperative was established in Ambelakia in 1780 and the foundation of the first Polish cooperative named Rolnicze Towarzystwo Ratowania się w Nieszczęś sciach (Agricultural Society for Rescue in Misfortunes) took place in 1816 in Hrubieszów. SHAFFER (1999, 242, 337); CIOCH (2009, 26 - 35). In Serbia the first cooperative was founded in 1846 MIĆOVIĆ, (2017, 1206). 
The article also considers the credit union's legal situation when applying the structural form of the European Cooperative Society (Societas Cooperativa Europaea). In that matter the article considers the legal consequences of credit union's cross - border activity which occurs by relocation of credit union's registered office between European Union (EU) member states and by providing financial services in different EU member states.

In conclusion propositions of changes in Polish credit unions' regulation are provided. The propositions take into account the private and public law regulation diversity of credit unions' legal status. They also aim to provide compliance of regulation of credit unions in Polish law with the recognized worldwide standards on cooperatives and credit unions.

\section{Outline of the historical development of credit unions' movement in Poland}

The credit unions movement history is almost as long as history of cooperatives in general. In fact, credit unions took a significant part in creation of cooperative movement in the $19^{\text {th }}$ century which developed due to the need of self-help in the evolving industrial economy. First credit cooperatives were founded in Germany on a pattern of two models, Herman Schultze - Delitzsch's model and Friedrich Wilhelm Raiffeisen's model ${ }^{4}$.

The credit union movement in Poland developed in the late $19^{\text {th }}$ century in Polish southern territories by initiative of dr. Franciszek Stefczyk who introduced into Polish cooperatives' movement the Raiffeisen's credit cooperative model in order to remove poverty from rural environments. Stefczyk helped the foundation of the first Raiffeisen's pattern credit cooperative in 1890 in Czernichów, a village in southern Poland near Cracow. After that Stefczyk became one of the leaders of cooperative movement in Poland and the founder of the first in the world cooperative research institute 5 .

However, the foundation of the first Polish self-help credit organizations came even before Stefczyk's credit cooperative. Such organizations, called pious' banks developed in Poland in the $16^{\text {th }}$ century thanks to a catholic priest named Piotr Skarga. Therefore, the history

4 BIRCHALL (1997, $11-14)$.

5 SHAFFER $(1999,337)$. Tradition of this institute is nowadays continued by the Cooperative Research Institute in Sopot, Poland. 
of self-help credit organizations is even longer then the history of development of the Rochdale's cooperative model that underlies the fundamentals of nowadays cooperatives. Also, according to some historic sources, the first credit cooperative in Poland was founded in Lwów in 1844 regardless of Herman Schultze - Delitzsch's and Friedrich Wilhelm Raiffeisen's models. Similar situation occurred in the northern Poland, where the foundation of the first credit cooperative took place in $1861^{6}$.

By World War II 5000 credit unions were established in Poland ${ }^{7}$. After the war - under the communist regime - credit unions, although with limited autonomy, briefly re-established their operations before their subordination to National Bank and forced transformation to cooperatives banks in $1975^{8}$. The rebirth of the credit union movement in Poland took place after the fall of communist economy in 1989 and it should be considered as a great example of effective use of cooperatives in market economy. It is an example of great importance for the discussion of cooperatives place in the modern Polish economy as examples from the historical use of cooperatives for purpose of communist economy establishment may discourage the foundation of new cooperatives. In the past few years, there have even been voices that recognize cooperatives as ineffective forms of conducting business activity, whose development and autonomy need to be limited ${ }^{9}$. Such opinion has been strengthened by failures in introducing amendments to Polish Cooperative Act of 16 of September 1982 ${ }^{10}$. However, nowadays this opinions seems to vanish and the usage of cooperatives in conducting business activity in Poland should increase due to new regulations concerning farmers' cooperatives which, among others, provide new solutions regarding transfer of cooperative shares and second tiers cooperatives (farmers cooperatives' associations) ${ }^{11}$. On the other hand, still strong is the understanding of cooperatives rather as institutions established to fulfill public duties that remains the state obligations (for example an obligation to meet housing needs of the soci-

6 JEDLIŃSKI (2002, 22); ZAKRZEWSKI (2002, 162).

7 CHMIELEWSKI $(1936,49)$.

8 JEDLIŃSKI (2002, 21 - 24).

9 Criticisms of this approach was carried out by JEDLIŃSKI $(2014,11)$.

10 Journal of Laws 2018 item 1285 with further changes.

11 Under Polish law as second tier cooperative should be considered both: cooperatives founded only by legal entities (not only cooperatives but also other kinds of legal entities, for example commercial companies) and cooperative organizations that are: cooperatives' revision associations, cooperatives' economic associations and farmers cooperatives' associations. 
ety as in case of housing cooperatives) than as entrepreneurs founded to meet members' common needs and to conduct business activity in their interest.

With the involvement of the World Council of Credit Unions the first credit union in the regain market economy in Poland was founded in 1992. The credit unions movement developed quickly reaching in 2001 a number of 500,000 members ${ }^{12}$ and in 2013 a number of 2,660,00013. In 2017 the number of credit unions members stated at 1,708,636. However, even after recession in the number of members, Polish credit unions system remains one of the most developed credit unions movements in the world, currently with third number of members in Europe after Ireland and Great Britain ${ }^{14}$. From the legal point of view it should be stated that the development of credit unions benefited from freedom of contracts in the field of founding the cooperatives that are credit unions. Founding a cooperative under Polish law takes place by conducting a private law agreement resulting in executing by the cooperative founders 1) the freedom of choosing whether or not to contract 2) the freedom of choosing the contractor and 3 ) the freedom of introducing agreed provisions to a contract within limits of legality (jointly referred as freedom of contracts) ${ }^{15}$. These rules express in the positive private law the rule of freedom of association in the cooperative i.e. $1^{\text {st }}$ Rochdale Principle ${ }^{16}$.

12 JEDLIŃSKI $(2002,26)$.

13 WORLD COUNCIL OF CREDIT UNIONS (2013).

14 WORLD COUNCIL OF CREDIT UNIONS (2017).

15 PIETRZYKOWSKI (1990, 95, 101); STELMACHOWSKI $(1998,91)$. Polish law does not explicitly indicate the elements consisting on the freedom of contract, like for example French law does (art. 1102 of Code Civil). However, it is considered that such freedom consist of four elements: 1) freedom of choosing whether or not to contract, 2) freedom of choosing a contractor, 3) freedom of introducing agreed provisions to a contract within limits of legality, and 4) freedom of choosing within limits of legality the legal form of the contract. However, there are also opinions which exclude the freedom of form of the contract from the contents of the principle of freedom of contract. These opinions indicate that the legal form of legal action (for example form of notarial deed) serves as a conveyor of specific information that is a declaration of will and that freedom of choosing a legal form of legal action should be considered as the separate legal principle than freedom of contract. RADWAŃSKI (1977, $101-103)$; GROCHOWSKI (2017, $14-17$ and 2018, $64-67)$. Also, it should be noted that English legal doctrine provides a distinction between a freedom to contract (freedom to choose whether or not to contract) and freedom of contract (freedom of introducing agreed provisions to a contract within limits of legality). PEEL (2007, 2 - 3). On freedom of contract see: FRIDMAN (1967, 1 - 22).

16 PIETRZYKOWSKI $(2012,296)$. 
The development of credit unions' system in Poland has took a step back since the introduction of state supervision performed by the Financial Supervision Authority (FSA) ${ }^{17}$. This supervision is performed under the administrative law regime which has influence on credit unions foundation and in mastering their functioning by the FSA also in terms of their liquidation of credit unions and takeover of their assets by other financial institutions (credit unions but also cooperative and commercial banks). Since 2012 when this supervision has been introduced the number of credit unions in Poland declined from 55 in 2012 to 28 in 2019. This situation occurred especially as a consequence of 1) limiting freedom of conducting a contract on founding of a credit union by establishing a requirement of receiving a contract permission from the FSA, 2) credit unions mergers which are encouraged by the FSA 3) but also as a consequence of credit unions compulsory takeover by commercial and cooperative banks and liquidation of credit unions by the FSA's decision due to their insolvency.

It is safe to say that instruments used by the FSA for conducting the supervision over credit unions were not adequate to its specific nature as there were transferred from supervisory experience over commercial banks. This led to lack of possibility of adjusting credit unions activity to the FSA's requirements because credit unions do not conduct activity on open financial markets. As credit unions, unlike banks, can only provide indicated financial services (collecting deposits, granting loans and credits, providing financial settlements) and only to their members they cannot compete for customers with other entities providing financial services such as commercial and cooperative banks ${ }^{18}$. The legal character and economic purpose of credit union's transactions with its members leads to the conclusion that a credit union is a consumer cooperative ${ }^{19}$. However, in Polish legal system exists a connection between membership and credit union's services consumer status. This connection is absolute as termination of membership in the credit union results in termination of members contracts under which the credit unions is obligated to collect member's deposits, provide financial settlements or grant a loan

17 The Financial Supervision Authority is a administrative body dedicated to conduct supervision over financial market in Poland which includes credit unions sector but also banking, insurance companies and financial instruments sectors. In Poland, there is an integrated supervision over the financial market, which is exercised by the FSA. POWAŁOWSKI $(2017,257-258)$.

18 JEDLIŃSKI $(2002,66)$.

$19 \mathrm{FICl}(2013,24)$. 
or a credit 20 . Moreover, credit unions in Poland constitute a part of the financial market however, they are deprived of any financial instruments other than bonds, for example securities such as stocks, swaps, call and put options etc. For this reason, credit unions do not involve significant number of third parties in their activities, as there are almost no financial instruments that could be acquired by such persons (no credit union in Poland had issued bonds yet). This situation should be taken into account by the FSA while conducting the supervision over credit unions. Unfortunately the introduction of the FSA's supervision over credit unions took place under different assumption consisting in identifying the activities and beneficiaries of credit unions with the activities and beneficiaries of banks. This clearly wrong assumption was even regarded in certain Polish Supreme Court judgements (of $16^{\text {th }}$ of January 2008, case number IV CSK 462/07 and of $10^{\text {th }}$ of April 2013, case number IV CSK 542/12). On the other hand however, credit unions are limited by the FSA in promoting their activities (which are performed also by commercial and cooperative banks) such as deposits collecting. Fortunately, the supervision adequacy issue was considered by the Polish Constitutional Tribunal21 in its judgement from 31 of July 2015 (case number $\mathrm{K} 41 / 12$ ) as the court indicated that supervision of the FSA over credit unions should be conducted while taking into account the complexity and scale of their activity and the scale of risk occurring in the activity. This thesis is now reflected in articles 60 and 61 of the PCUA.

\section{Credit unions' legal status}

\section{III.1. Cooperative status}

Credit unions in Poland are primary subject to the PCUA. Article 2 of the PCUA states that a credit union is a cooperative subject to the general act on cooperatives (lex generali), i.e. the PCA, unless other-

20 Article 4 of the 5 of November 2009 Polish Credit Unions Act (Journal of Laws 2018 item 2385 with further changers), further referred as: PCUA, explicitly indicates that the membership relation is separate from relationships arising from member's contracts on credit union's services as the act states that to those contractual relations provisions on protection of consumer collective interests applies.

21 In Poland the Constitutional Tribunal is the court competent to issue a judgment causing the loss of power by the provision of the act in the event of its non-compliance with the Constitution (Article 190 of $2^{\text {nd }}$ of April 1997 Constitution of Republic of Poland, Journal of Laws 1997, no. 78, item 483 with further changes). 
wise indicated by the PCUA 22 . Article 1 paragraph 1 of the PCA, on the other hand, provides the legal definition of a cooperative in Polish law. This provision states that "The cooperative is a voluntary association of an unlimited number of people with a variable personal composition and a variable participation fund, which in the interest of its members carries out joint business activities". Also, according to article 1 paragraph 2 of the PCA "A cooperative may conduct social and educational-cultural activities for its members and their communities". The legal definition of a cooperative provided by the PCA applies to credit unions as the PCUA does not provides any other regulation on this matter. This definition expresses the fundamental characteristics of a cooperative (yet not all of them in comparison with the International Cooperative Principles), i.e. voluntary membership, unlimited members number and members economic participation.

22 In Poland there is one general cooperative law and a number of laws that apply to specific kinds of cooperatives. It is not however a case in all of the EU member states. For example in Greece there is no general law on cooperatives, however, there are separate laws on rural cooperatives (L. 4384/2016), forest cooperatives (L. 4423/2016), urban/civil cooperatives (L. 1667/1986) which are active in any type of sector apart from agriculture, social cooperatives (art. 12 of L. 2716/1999), energy cooperatives (L. 4513/2018), social cooperative enterprises and workers cooperatives which operate under law on social and solidarity economy (L.4430/2016). KORNILAKIS (2017, 206 - 208).

In Poland, 1st title of 1st part of the PCA contains regulations of lex generali character for all kinds of cooperatives. The regulation of lex specialis character on specific kinds of cooperatives is included in 2nd title of 1st part of the PCA which governs workers cooperatives and agricultural cooperatives. Also, the regulation of lex specialis character on specific kinds of cooperatives is included in a number of separate legal acts form PCA. These separate acts are:

1. 7th of December 2000 Act on the Functioning of Cooperative Banks, their Associations and Affiliating Banks (Journal of Laws 2018, item 613 with further changes).

2. 15th of December 2000 Act on Housing Cooperatives (Journal of Laws 2018, item 845 with further changes),

3. 27th of April 2006 Act on Social Cooperatives (Journal of Laws 2018, item 1205),

4. 22nd of July 2006 Act on European Cooperative Society (Journal of Laws 2018, item 2043 with further changes) which is the implementation of the Council Directive 2003/72/EC of 22 July 2003 supplementing the Statute for a European Cooperative Society with regard to the involvement of employees (Official Journal of the European Union 18.8.2003, L 207/25), further referred as SCED.

5. 5th of November 2009 Act on Credit Unions (PCUA),

6. 4th of October 2018 Act on Farmers' Cooperatives (Journal of Laws 2018, item 2073),

7. also the 20th of February 2015 Act on Renewable Energy Sources (Journal of Laws 2018, item 2389 with further changes) contains regulation of energy cooperatives. 


\section{1.1. MeMBERSHIP COMMON BOND}

The PCUA regulation does not violate the already mentioned characteristics of the cooperative which are expressed by article 1 paragraph 1 of the PCA, i.e. voluntary membership, unlimited members number and members economic participation. Also, the PCUA clarifies the general purpose of a cooperative (conducting business activity in the interests of its members) by expressing the purpose of a credit union that is providing financial services for credit union's members. The business activity of the credit union is conducted jointly with its members. They are always user members as all of them should benefit from the credit union's services. Also, Polish cooperative law does not provide the possibility of investors' membership in credit unions as well as in other kinds of cooperatives.

The statutory field of credit unions' business activities is granting loans and credits only to their members, collecting their members deposits and provide them with financial settlements ${ }^{23}$. The allowed by the Polish legislator field of credit unions' activities reflects their assumption as members owned cooperatives established to conduct business activity in the interest of their members. This assumption should be also inferred from the obligatory common bond connection between all of the credit union's members. Membership common bond between credit unions' members is an internationally recognized requirement and it derives from Raiffeisen's credit cooperative model. It is also recognized by the WOCCU24.

The common bond between credit union members underlies the membership relationship in the credit union. However this bond is of social (teleological) but not of legal nature and its existence does not influence the contents of legal rights of a credit union member ${ }^{25}$. The common bond between Polish credit union members could be of or-

23 Polish legal system does not establish specific regulation for legal actions conducted between cooperatives and their members as do certain other legal systems (for example Spanish, Portuguese or Uruguayan cooperative law - actos cooperativos). MÜNKER $(2016,6)$. According to the principle of unity of civil law, contracts and other legal actions conduced by the cooperative and its members are subject to general regulations on legal actions. Different situation however occurred before World War II, when Polish law was characterized by dualism in civil and commercial law regulation. At this time, under the 29 of October 1920 Act on Cooperatives and 27 of June 1934 Commercial Code, legal actions conducted by cooperatives were subject to regulation on commercial actions (acte de commerce), i.e. actions conducted by merchant with relation to business or economic activity. DIERŻANOWSKI (1938, 14 - 15).

24 Model Law for Credit Unions $(2015,23)$.

25 JEDLIŃSKI (2002, 74 - 75); BIERECKI (2013, 42 - 45). 
ganizational or professional character. In particular (but not only) it could be the bond between employees employed in one or more workplaces or the bond between members of the same social or professional organization (article 10 paragraph 1 of PCUA). It should be noted that Polish law does not recognize the territorial common bond as membership social bond. It as a significant credit unions' regulation defect as territorial common bond, for example existing due to common place of residence, work or business activity is one of the strongest and also obvious social bonds. This kind of common bond dates back to Raiffeisen's and also Stefczyk's credit cooperatives. It could be also mentioned that the territorial common bond is recognized in the United States of America ${ }^{26}$ which has the most developed credit unions' system in the world in terms of members number and assets ${ }^{27}$. In Europe territorial common bond is recognized by law in Ireland, Lithuania and Great Britain28.

Also, the possibility of second tier common bond (meta bond) between credit union's members exist ${ }^{29}$. The meta bond exist between social groups constituted by the indicated first tier common bond. The existence of the meta bond allows the foundation of the credit union between persons associate in different social organizations or legal organizations. In addition, the meta bond between members of certain legal persons also allows this legal organizations to became members of the credit union. However, article 10 paragraph 2 of the PCUA exhaustively indicates legal persons eligible to acquire the membership in the credit union. These legal persons should be: 1) non-governmental organizations indicated by article 3 paragraph 2 of 24 ${ }^{\text {th }}$ of April 2003 Act on Public Benefit Activities and Volunteering 30 , 2) organizational units of churches and religious associations, both with legal personalities, 3) cooperatives (lege non distinguente also credit unions), 4) trade unions and 5 ) housing communities.

Moreover, it should be noted that credit unions in Poland can provide certain services not only for their members but also for nonmembers, i.e. persons outside the common bond between all of the credit union's members (outside the field of membership). However, those services are strictly expressed by the PCUA. This situation complies with the WOCCU standards. Assumption of credit unions as members owned

26 EMMONS and SCHMID (1999, $41-64)$.

27 WORLD COUNCIL OF CREDIT UNIONS (2017).

28 SKOCZEK $(2013,99,102,104)$.

29 JEDLIŃSKI (2002, 64 - 80); BIERECKI (2013, 38 - 45).

30 Journal of Laws 2019, item 688 with further changes. 
savings institutions does not allows nonmembers deposits collecting and granting loans or credits to nonmembers. Financial services provided by the credit union to nonmembers cannot impact its assets or liability. Services provided to nonmembers should also be fee-based ${ }^{31}$.

Credit unions in Poland can mediate in concluding insurance contracts (either as insurance agent or insurance broker) between its members as well as nonmembers and insurance companies. Also, credit unions can mediate in conducting sell and purchase agreements of investment fund participation units or participation titles of foreign funds and open-end investment funds based in countries belonging to the European Economic Area (EEA) ${ }^{32}$. However, providing these services requires a permission from the FSA. On the other hand, such permission is not required in case of mediating in concluding insurance contracts as credit unions legal title to provide such services results directly form the PCUA.

\section{III.2. Entrepreneur status}

The application of the legal definition of a cooperative to credit unions and their legal purpose leads to a conclusion that credit unions are entrepreneurs in the matter regarded by article $43^{1}$ of $23^{\text {rd }}$ of April 1964 Polish Civil Code 33 (PCC), i.e. credit unions conduct economic activity on they own behalf ${ }^{34}$. As cooperative law is a special part of private law the PCC regulations applies directly to all kinds of cooperatives. The PCC regulations does not apply to cooperatives with any modifications as it may happen in the case of commercial companies due to a nature of commercial company (according to article 2 of $15^{\text {th }}$ of September 2000 Polish Code on Commercial Companies ${ }^{35}$ ). No modifications are also allowed while applying to the cooperative the legal definition of an entrepreneur.

31 Model Law for Credit Unions $(2015,13,23)$.

32 ZAKRZEWSKI (2014, 38 - 39).

33 Journal of Laws 2019, item 1145 with further changes.

34 As the PCA indicates that cooperatives conduct economic activity and the PCC states that economic activity is the characteristic of an entrepreneurs, neither of this legal acts provides the economic activity definition. Polish private and public law provides several definitions of economic activity. It is however unanimously accepted that an economic activity definition that applies to private law entities (including cooperatives) is provided by the $6^{\text {th }}$ of March 2018 Act - Entrepreneurs Law which article 3 states that an economic activity is an organized gainful activity, carried out on own behalf and on a continuous basis.

35 Journal of Laws 2019, item 505 with further changes. 
Therefore, undoubtedly, the expressed by article 1 paragraph 1 of the PCA characteristic of a cooperative that is conducting business activity by the cooperative in the interest of its members should be considered in economical manner, i.e. as benefits that arise from the membership in the cooperative. Such benefits vary depending on different kinds of cooperatives. For example in housing cooperatives such benefit is a title to a flat, dwelling or habitation that only cooperative member can acquire or in workers cooperative it is the salary payed to the member next to the cooperative balance surplus. In case of credit unions such benefits are financial services provided by the credit union. In this case such benefits occur as a consequence of strengthening cooperative capital by deducting all of the balance surplus on the credit union's statutory funds.

It should be stated that credit unions in Poland conduct not for profit business activity as their economic profits are exclusively deducted to meet their statutory objectives and not distributed between their members ${ }^{36}$. This assumption complies with the WOCCU Bylaws as its article II paragraph 2.3. states that "Credit union means a cooperative financial services organization owned and operated by its members on a not for profit basis according to democratic principles. Its purpose is to encourage savings, to use pooled funds, to make loans, and to provide other related services to members and their families. A credit union is part of a cooperative financial system and adheres to the operating principles for credit unions as set forth by WOCCU"37.

\section{III.3. Credit union's status on financial market}

Credit unions system in Poland is regarded by law as a part of the financial market (article 1 paragraph 2 point 7 of $21^{\text {st }}$ of July 2006 Act on Supervision over Financial Market ${ }^{38}$ ). Because of that, credit unions are subject to legal norms not only of private law but also of administrative law characteristic. These administrative norms are included in the PCUA and in the already mentioned Act on Supervision over Financial Market, i.e. the legal act that governs the financial market by establishing the supervision of the FSA. Also, the $10^{\text {th }}$ of June 2016 Act on Banking Guarantee Fund Deposit Guarantee System and Forced

36 JEDLIŃSKI (2002, 39 - 42); ZALCEWICZ (2013, 35, 40, 41); BIERECKI $(2017,69)$.

On characteristics of not for profit activity see: BATIZ-LAZO and BILLINGS $(2012,311)$.

37 https://www.woccu.org/documents/WOCCU_Bylaws_2017; access: 29.06.2019.

38 Journal of Laws 2019, item 298 with further changes. 
Restructuring ${ }^{39}$ applies to credit unions in particular in extend of collected deposits guarantee by the Banking Guarantee Fund. Moreover, administrative legal norm included in the $27^{\text {th }}$ of May 2004 Act on Investments Funds and Management of Alternative Investment Funds 40 (articles 32 paragraphs $2-10$ and 32a paragraphs $1-7$ ) may apply to the credit union if its services include mediating in sales and purchases agreements of investment fund participation units or participation titles of foreign funds and open-end investment funds based in countries belonging to the European Economic Area (EEA) ${ }^{41}$.

Therefore, the legal regulation of cooperatives that are credit unions is characterized by certain duality. On the one hand credit unions are regulated by private law regime which guarantees the freedom of contract which arises from the private law regulation method assuming equality of legal parties and lack of possibility of imperious shaping the legal situation of another parties ${ }^{42}$. Such situation expresses in the legal sense the principle of autonomy and independence of cooperatives ( $4^{\text {th }}$ Rochdale Principle).

However, on the other hand, administrative legal norms which apply to credit unions disregards they autonomy as these norms allow state authorities to impose specific orders and prohibitions on credit unions $^{43}$. If such orders or prohibitions relate to the subject of the cooperative's activity and the possibility of associating in them, we are dealing with a violation of the autonomy of the cooperative.

A good example of such violation are situations occurring in credit unions financial system with regard to members participation in credit union's losses. According to the PCA cooperative's members participate in cooperative's losses up to the amount of the declared shares. However,

39 Journal of Laws 2019, item 795 with further changes.

40 Journal of Laws 2018, item 1355 with further changes.

41 It should be noted that credit unions are among financial institutions excluded from the application of the CRD IV/CRR Package, i.e. Directive 2013/36/UE of the European Parliament and of the Council of 26 th June 2013 on access to the activity of credit institutions and the prudential supervision of credit institutions and investment firms, amending Directive 2002/87/EC and repealing Directives 2006/48/EC and 2006/49/EC (Official Journal of the European Union of 27.6.2013, L 176/338) and Regulation (EU) No 575/2013 of the European Parliament and of the Council of 26 th June 2013 on prudential requirements for credit institutions and investment firms and amending Regulation (EU) No 648/2012 (Official Journal of the European Union of 27.6.2013, L 176/1). Article 2 paragraph 5 point 18 of the Directive 2013/36/UE excludes credit unions in Poland from the Directive application. On the other hand, Regulation (EU) No 575/2013 applies only to entities subject to the Directive 2013/36/UE.

42 GRZYBOWSKI (1985, 179); SAFJAN $(2012,38-43)$.

$43 \operatorname{HAUSER}(2010,195$ - 200). 
the PCUA allows to include into the credit union's bylaws provisions increasing the participation of members in the credit union's losses up to double value of the declared shares. At the certain point of time it was common for credit unions to introduce into their bylaws such provisions with the permission from the FSA which by law approves credit unions' bylaws' changes. However, decisions of certain credit unions to remove such provisions from their bylaws were not approved by the FSA. As mentioned, such decisions of the FSA rises doubts in relation with the principle of cooperative autonomy. Coverage of the credit union's losses from doubled value of members' declared shares may occur only under the decision of the credit union's general meeting ${ }^{44}$. This kind of members' economic participation in the cooperative (credit union) may occur only with compliance with the principle of democratic member control ${ }^{45}$. This legal institution has rather the character of voluntary payment than security of credit union's financial standing. It's not an instrument allowing external investors to secure their claims against the credit union as it does not arise members subsidiary or joint and several liability for credit union's debts. In principle, members are nor liable for cooperative debts. Nor this institution could be considered as an instrument protecting consumers from credit union's insolvency ${ }^{46}$. Regarding credit unions' bylaws changes, such FSA's decisions led to a situation in which credit unions' members are limited in conducting their joint business activity as a result of determining various prudential standards and authoritative decisions of the FSA regarding the further functioning and development of credit unions.

44 ADAMUS $2019(26,35-40)$.

45 On $12^{\text {th }}$ of December 2019 (case number III CZP 42/19) the Polish Supreme Court provided a judgement supporting this point of view.

46 Argument of consumer protection on financial markets should not interfere with the credit union's essence as self-help institution, the character of which result's from the joint participation of members in the economic activity conducted by their cooperative (credit union). Regarding consumer protection issue it is understandable that granting loans or credits for consumers should be restricted to certain situations regarding maximum loan or credit cost and interests as well as providing consumers with certain information on those matters. It cannot be excluded that contract provisions which are hostile for consumers could not be stipulated by credit unions which provide services only in case when consumers are their members. Therefore, the $12^{\text {th }}$ of May 2011 Act on Consumer's Credit (Journal of Laws 2019, item 1083), which is the implementation of the Directive 2008/48/EC of the European Parliament and of the Council of $23^{\text {rd }}$ of April 2008 on credit agreements for consumers and repealing Council Directive 87/102/EEC (Official Journal of the European Union 22.5.2008, L 133/66), applies to loans and credits granted by credit unions. This act defines credit unions' obligations regarding information provided to consumers before the conclusion of the loan or credit agreement. 


\section{The credit union as the European Cooperative Society and cross-border activity of the credit union}

The European Cooperative Society (Societas Cooperativa Europaea), i.e. the SCE, was introduced into the European Union legal system by way of regulation ${ }^{47}$. In the European Union law the regulation is a legal act that has general scope, binds in its entirety and is directly applicable in all member states without necessity of its implementation by national authorities (article 288 paragraph 2 of the TFUE ${ }^{48}$ ). An issued regulation becomes a part of the legal system of the EU member state. Therefore, the SCER is an element of Polish cooperative law.

Because of direct application of the SCER in entire EU, the SCE has legal personality granted in every EU member state, regardless of place of its registered office (which could be in any EU member state) and applicable national regulation (article 1 paragraph 5 of the SCER). According to article 8 paragraph 1 of the SCER, the SCE is primary subject to the SCER provisions. Secondly, also according to the indicated paragraph, the SCE is subject to national legal regulations issued for implementation of the SCED. In Poland such regulation is contained in the $22^{\text {nd }}$ of July 2006 Act on the European Cooperative Society ${ }^{49}$. Thirdly, still based on the indicated paragraph, the SCE is regulated by national regulations on cooperatives of the member state of its registered office. In Poland such regulation is contained in the PCA (lex generali) and in regulations of lex specialis character to this general act. Finally, lastly, the functioning of the SCE is governed by the provisions of its statute on the same terms as for cooperatives formed in accordance with the law of the EU member state in which the SCE has its registered office. In addition, SCER contains provisions referring to national regulations regarding public limited companies (e.g. article 20 of the SCER).

Application of above indicated regulations depends on the contents of the agreement upon founding of the cooperative. If the cooperative statute, which is according to Polish legal doctrine an element

47 Council Regulation (EC) No 1435/2003 of 22 July 2003 on the Statute for a European Cooperative Society (SCE) (Official Journal of the European Union 18.8.2003, L 207/1), further referred as SCER. Regarding employee involvement in the management of cooperative enterprise the SCER is supplemented by Council Directive 2003/72/EC of 22 July 2003 supplementing the Statute for a European Cooperative Society with regard to the involvement of employees (SCED).

48 Treaty on the Functioning of the European Union (Official Journal of the European Union of 26.10.2012, C 326/47), also referred as Treaty.

49 Journal of Laws 2018, item 2043 with further changes. 
of such an agreement ${ }^{50}$, indicates that the structural form of the SCE is applied by the credit union, the PCUA shall apply (which relative to the PCA expresses the lex specialis regulation). The SCE is a different kind of a cooperative because of the structure of its bodies (general assembly and depending on application of dualistic or monistic governance model: management board and supervisory board or board of directors) and the contents of membership in the SCE ${ }^{51}$. However, this SCE's specific features do not constitute its whole regulation and the need for application of indicated above national regulations also apply. Therefore, it is possible to find features established by member states cooperative laws in every SCE ${ }^{52}$. Because of that, in my opinion, the SCE should be considered as a cooperative's structural form which can be applied by every cooperative (including a credit union) in order to conduct activity in the in cross-border dimension without limitations ${ }^{53}$. This activity is possible because legal personality is granted to the SCE in every EU member state and because of possibility to transfer SCE's registered office from one EU member state to another without the SCE liquidation and its reestablishment in the country of SCE'S new registered office. The cross-border transfer of the SCE's registered

50 PIETRZYKOWSKI (1990,

51 This assumption is also accepted in CRACOGNA, FICI AND HENRY $(2013,118-$ 119). In the Judgement of $2^{\text {nd }}$ of May 2006, in case C-436/03, the European Court of Justice indicated that the SCE is a new and separate kind of cooperative with European character which exists next to national types of cooperatives. Therefore, the SCE's regulation is not intended to harmonize national cooperative laws by introducing the possibility of application of the SCE legal form. On that matter see: PAPADOPOULOS (2010, $26-27)$.

52 Therefore, it was stated in the international and Polish literature that there is no single SCE but as many SCEs as there are EU member states. HENRY $(2012,46)$; WRZOŁEK - ROMAŃCZUK $(2003,26)$; SZUMAŃSKI $(2008,29)$.

53 BIERECKI $(2017,63-64)$. An interesting matter occurs when the SCE is founded under French or Italian law. In these legal systems, otherwise then in Polish, German, Austrian, Swiss, Portuguese and Spanish law, a cooperative is not a separate type of legal entity. In France the nature of the cooperative may be adopted by a limited liability company, a joint stock company or a simplified joint stock company. In Italy the cooperative is a type of company regulated by the provisions of the Italian Civil Code, special laws on particular types of cooperatives and to some extend by joint stock companies as well as limited liability companies regulations. MÜNKER $(2016,6)$; AMMIRATO (2018, 25 - 39); SUCHOŃ (2015, 105 - 108); FAJARDO et. al. (2017, 348 350, 413 - 415); GUINNANE (2011, 70); ZAKRZEWSKI (2017, 526 - 528). It should be stated that in case of the foundation of the SCE under French or Italian law the company applies the structural form of the SCE and the applicable laws on cooperatives and companies apply further on in case of lack of SCER provisions. Because the SCE is a separate kind of cooperative the nature of the cooperative is adopted by the company by foundation of the SCE and not by application of national cooperative's structure. 
office effects in application to the SCE of law of the country of its new registered office. This law applies in both to SCE's internal structure (pro foro interno), for example to matters regarding SCE's management board or supervisory board, and to private law relationships with third parties (pro foro externo) other than private law relationships established before the cross-border transfer of SCE's registered office (article 7 paragraph 10,13 and 16 of SCER). The cross-border transfer of SCE'S registered office provides different legal consequences than cross-border transfer of legal entity's head office on the grounds of the Treaty's freedom of companies establishment (article 49 of TFUE) which results in application of entity's founding state law to its internal structure (pro foro interno) but new head office's country law to private law relationships with third parties (pro foro externo).

The credit union which applied the SCE structural form (SCE/credit union) can provide its financial services not only in the EU member state of its registered office but also in other EU member states. There are two situations to consider in this matter. First of all, the SCE/credit union can transfer its registered office to every EU member state accordingly to principles discussed above. In this regard it should be noted that the SCER indicates that the FSA can oppose the transfer of registered office of the supervised SCE (article 7 paragraph 14 of the SCER). However, it should be noted that due to the Treaty freedom of establishment, the SCE/credit union should not be required to apply to the financial supervision authority of the member state of its new registered office for the permission for conducting its activity. The permission for founding of the credit union issued by the FSA should be sufficient to conduct activity in other than Poland EU member state.

Secondly, due to SCE's legal personality in every EU member state the SCE should be recognized in the whole EU as an legal entity and thus it can conduct legal actions and economic activity in all of EU member states. Moreover, article 9 of the SCER establish the prohibition of discrimination of the SCE against cooperatives founded under the EU members states' laws. This discrimination cannot occur in relation to state authorities and other legal entities including cooperatives. The SCE/credit union should be able to provide its financial services on the same terms as credit union founded under members state's law both in the state of SCE's registered office and in other EU member states. By providing services in other member state than state of its registered office the SCE shall benefit from the Treaty freedom of services (art. 56 of TFUE). In this regard the SCE/credit union does not require to receive any permission from EU member state's financial authority other than financial authority of the SCE's registered of- 
fice member state ${ }^{54}$. The permission granted by SCE's registered office member state financial authority shall be sufficient. Therefore in Poland, the FSA's permission on founding of the credit union is sufficient to conduct activity by the SCE/credit union in cross-border dimension. Because of application of the freedom of services, it should be also stated that the same situation occurs in regard of the credit union that is not a SCE.

However, it should be noted that providing services by the credit union (also when the credit union applies the structural form of the SCE) is possible only to its foreign members who are connected with the membership common bond with other credit union's members. This situation occurs when the common bond is constituted by membership in organization with registered or head office in other EU member state than state of credit union's registered or head office. This situation also occurs when a foreigner works either conduct professional activity in other EU member state than credit union's office member state and by some reason is connected with the membership common bond with other credit unions members (for example, a foreigner works in foreign establishment or subsidiary of Polish company). In those events contracts concluded between the foreign member and the credit union are subject to EU member states laws accordingly with the Regulation (EC) No 593/2008 of the European Parliament and of the Council of 17 June 2008 on the law applicable to contractual obligations (Rome I) ${ }^{55}$. Contracting parties (credit union and its foreign member) can choose the applicable law (article 3 paragraph 1 of the Rome I regulation). If not, in principle, the contract on granting a credit or a loan or the contracts on providing financial settlements, collecting deposits and mediation in conducting insurance contracts and sell and purchase agreements of investment fund participation units or participation titles of foreign funds and open-end investment funds based in countries belonging to the European Economic Area (EEA) shall be governed by law of credit union's office country (article 4 paragraphs 1 (b), 2, 3 and 4 of the Rome I regulation). However, if either of those contracts between the credit union and its foreign member is to be considered as the consumer contract, it should be governed under law of foreign member's (consumer's) country (article 6 paragraph 1 (a) of the Rome I regulation).

54 It should be noted that exclusion of credit unions from the application of Directive 2013/36/EU, which contains provisions on supervision of credit and financial institutions cross-border activity by authorities of host country and country of origin (articles $33-46$ ), does not prevent credit unions cross-border activity.

55 Official Journal of the European Union 4.7.2008, L 177/6. 
The presented solutions on cross-border activity of credit unions, including the application of the SCE structural form by the credit union, comply with the WOCCU standards which indicate the necessity of recognition of credit unions formed under another jurisdiction because of the need to provide services to members employed in multi-country organizations ${ }^{56}$. In fact the solutions included in the EU law go even further than WOCCU standards. These standards indicate the possibility for credit unions to apply for a license for carrying out activity in country other than country of its office. However, cross-border transfer of SCE's registered office, the freedom of establishment and freedom of services allows credit unions to conduct their activity in cross-border dimension without the need to receive any approval from financial supervision authority of the EU member state of new credit union's activity.

\section{Conclusions}

Supervision over credit unions is an international standard approved by the WOCCU ${ }^{57}$. However, it should be stated that its scope should be limited to credit unions' financial standing evaluation. The supervision over credit unions should be conducted with regard to adequacy of supervision instruments in relation to legal character and complexity of activity of credit unions. This thesis is already supported by the PCUA. However this general assumption should be also supported by specific legal regulations.

Firstly, it should be stated that the FSA's permission requirement should not apply to credit unions' foundations as no minimum capital is required in this process and during credit unions' activities various financial ratios' scales apply (total assets to capital ratio, solvency ratio, capital adequacy ratio, liquidity ratio, funding ratio). It should be considered that a credit union is founded by its members with assumption of maximum scale of loans or credits which could be granted from members' shares and other payments conducted on credit union's account due to acquisition of a membership. This assumption is expressed in the WOCCU Bylaws as its article II paragraph 2.3. states that a credit union's purpose is to encourage savings, to use pooled funds, to make loans, and to provide other related services to members and their families. In my opinion, the PCUA

56 Model Law for Credit Unions $(2015,18-19)$.
57 Model Law for Credit Unions $(2015,50-58)$. 
should be amended by removing the requirement of FSA's permission for foundation of a credit union. However, due to the financial market necessity of safety of its members, a requirement of FSA's authorization for start of credit union's operations should be introduced. It should be noted that Directive 2013/36/EU of the European Parliament and of the Council of 26 June 2013 on access to the activity of credit institutions and the prudential supervision of credit institutions and investment firms (which, however, does not apply to credit unions) indicates that EU member states should require credit institutions to apply before beginning operations for authorization by which the right to carry out the business is granted. Bearing in mind this requirement of the 2013/36/EU Directive it should be noted that the PCUA requirement for permission of foundation of the credit union is not proportional to the EU law standards. However, it should be also noted that banks in Poland require separate permission for foundation and for beginning of operations. Comparing credit unions and banks in that matter one could argue that credit unions are privilege as they do not require to receive two separate permissions or authorizations. However, modification of the requirement of receiving the permission for foundation to the requirement of receiving the permission for start of operations would comply with the $1^{\text {st }}$ Rochdale Principle, i.e. voluntary and open membership. Also, authorization to carry out business should indicate that the credit union has the actual ability to satisfy needs of its members and to conduct its statutory financial services. The obligation to receive this kind of authorization by the credit union would be related with the cooperative's obligation to conduct business activity. As indicated before, a cooperative should conduct business activity in the interest of its members. If such activity has not been conducted by the cooperative, the cooperative revision association or the National Cooperative Councili58 can

58 The National Cooperative Council is a statutory legal person and the supreme body of cooperative self-government. It performs the function of a cooperative revision association for cooperatives that are not affiliated in such an association. This does not mean, however, that such cooperatives are associated in the National Cooperative Council. The National Cooperative Council does not constitute a first or second tier cooperative. The National Cooperative Council performs a number of tasks specified in statutes and commissioned by the Cooperative Congress. The Cooperative Congress is the highest body of cooperative self-government. It is convened every 4 years by the National Cooperative Council. The Cooperative Congress assesses the condition of cooperatives in Poland and the conditions and possibilities for its development, adopts the statute of the National Cooperative Council, the principles of financing its activities by cooperative organizations, selects members of the Council and determines the principles of dismissal of its members. 
adopt a resolution on cooperative's liquidation (article $114 \S 1$ pkt 3 of P(A) or in case when the cooperative has no assets it can be removed from the court registry which leads to cooperative's cessation (article 115 of PCA).

Secondly, the FSA's approval requirement should not apply to credit unions' bylaws changes which does not affect credit unions' financial standing. An example of such bylaws change is already mentioned removal of provision of members participation in the credit union's loses up to double value of declared shares. The other example is bylaws provision regarding credit union social and educational-cultural activity.

Thirdly, the credit unions regulation should be modified with regard to credit unions compulsory takeover due to their insolvency. In such case under the decision of the FSA, the credit union, cooperative or commercial bank with efficient financial standing acquires the insolvent credit union with all of its assets 59 . Due to such acquisition members of the insolvent (acquired) credit union become members of the acquiring credit union. However, due to the mandatory takeover of the credit union by the commercial or cooperative bank, members of the credit union does not acquire membership in the cooperative bank or acquire stocks of the commercial bank. The credit union's assets are designated for the credit union's creditors and the remaining balance is paid out to former credit union's members. This situation raises justified doubts as it leads to compulsory termination of membership in the credit union and for this reason violates the principle of voluntary membership in the cooperative ( $1^{\text {st }}$ Rochdale Principle of voluntary and open membership). Also, such situation raises doubts in the light of constitutionally protected right to property ${ }^{60}$ (article 64 of Constitution of Republic of Poland). Moreover it should be noted that similar regulation does not exist in case of commercial and cooperative banks insolvency which also raises doubts in the light of constitutional right of equality (art. 42 of Constitution of Republic of Poland). Credit unions are the only cooperatives which can be taken over regardless of its members agreement.

Fourthly, the legal regulation of credit unions in Poland requires changes with regard to cooperation between credit unions ( $7^{\text {th }}$ principle of cooperation between cooperatives). It should be noted that all credit unions in Poland associates in the National Association of Co-

$59 \operatorname{DUDA}(2018,53-55)$.

60 ZAKRZEWSKI $(2014,453)$. 
operative Savings and Credit Unions (NACSCU), a second tier cooperative of only credit unions which is obligated to ensure credit unions' financial stability and perform control over credit unions in order to ensure the security of the savings they accumulate and the compliance of their activity with legal provisions. However, credit unions in Poland should also develop cooperation outside the membership in the NACSCU. For this reason a credit union should be enabled to provide financial settlements for members of other credit union. This could help develop credit union's business strategies and provide a source of income without charging the assets of the credit union with the risk of loan or credit repayment.

Fifthly, it is necessary to increase attractiveness of credit unions as business entities by introducing new instruments encouraging members to invest in credit unions ( $3^{\text {rd }}$ principle of members economic participation). The introduction of the possibility of transferring cooperative shares should be indicated. The possibility of transferring shares is gradually introduced into Polish cooperative law. As already mentioned, recent changes in this area concern the possibility of transferring shares in farmers' cooperatives ${ }^{61}$. Also, this possibility exists in the SCE (article 4 paragraph 11 of the SCER) ${ }^{62}$. However, there is no justification for limiting this possibility only to certain cooperatives. Furthermore, regarding credit unions' attractiveness as business entities one should consider the introduction of investing member category to the PCUA. The legal institution of the investing member is present in the laws of several central Europe countries: in German ${ }^{63}$, Austrian ${ }^{64}$, and Hungarian ${ }^{65}$ law. However, the essence of such membership is be expressed in acquiring an investment share in exchange for transfer of property (money, generic goods or real estate accordingly with the cooperative statute) to the cooperative, as a result of which the investing member should acquire the right to participate in the balance surplus of the cooperative. As credit unions do not distribute balance surplus between their members, the investing member category could be attractive and useful only for the NACSCU which could acquire shares in credit unions in order to ensure them financial stability and provide them with financial support.

\footnotetext{
61 BIERECKI $(2019,82-83)$.

62 BIERECKI $(2017,255$ - 256, 265 - 266, 267 - 280).

63 MÜNKER $(2017,268) ; \operatorname{KOBER}(2010,37-49)$.

64 CRACOGNA, FICI AND HENRY $(2013,239)$.

65 CRACOGNA, FICI AND HENRY $(2013,440)$.
} 
Sixthly, it is also necessary to enable wider financing of the business activities of credit unions' members, for example by admitting the membership of partnerships whose members are members of credit unions. Thus, membership of general partnerships, professional partnerships, limited partnerships and limited joint-stock partnerships should be enabled in credit unions. The nature of partnerships indicates that they should be allowed to acquire membership in the credit union as they can be included as organizations that can be connected with members of the credit union with a second - tier common bond (meta bond) and, in principle, conduct economic activity with involvement of their members.

\section{References}

1. ADAMUS, RAFAŁ. 2019. "Zagadnienie odpowiedzialności za straty bilansowe członków spółdzielczej kasy oszczędnościowo - kredytowej." In Prawo prywatne w służbie społeczeństwu. Księga poświęcona pamięci Profesora Adama Jedlińskiego, edited by Piotr Zakrzewski and Dominik Bierecki, 23 - 44. Sopot: Wydawnictwo Spółdzielczego Instytutu Naukowego.

2. AMMIRATO, PIERO. 2018. The Growth of Italian Cooperatives. Innovation, Resilience and Social Responsibility. New York - London: Taylor \& Francis.

3. BA'TIZ-LAZO, BERNARDO and MARK BILLINGS. 2012. "New perspectives on not-for-profit financial institutions: Organizational form, performance and governance." Business History 54, no. 3: 309 - 324. http://dx.doi.org/ 10.1080/00076791.2011.638480

4. BIERECKI, DOMINIK. 2013. Członkostwo w spółdzielczej kasie oszczędnościowo - kredytowej. Sopot: Wydawnictwo Spółdzielczego Instytutu Naukowego.

5. BIERECKI, DOMINIK. 2017. Spółdzielnia europejska w świetle prawa polskiego. Sopot: Wydawnictwo Spółdzielczego Instytutu Naukowego.

6. BIERECKI, DOMINIK. 2019. "Zbycie udziału w spółdzielni rolników." Pieniądze i Więź, no. 1: 80 - 94.

7. CHMIELEWSKI, ZYGMUNT. 1936. Podręcznik spółdzielczości. Warsaw: Wydawnictwo Spółdzielczego Instytutu Naukowego.

8. CIOCH, HENRYK. 2009. Zarys prawa spółdzielczego. Warsaw: Wolter Kluwer.

9. CRACOGNA, DANTE, ANTONIO FICI and HAGEN HENRY, ed. 2013. International Handbook of Cooperative Law. Berlin - Heidelberg: Springer.

10. DUDA, DARIUSZ. 2018. "Przejęcie spółdzielczej kasy oszczędnościowo kredytowej na podstawie decyzji Komisji Nadzoru Finansowego." Prawo $i$ Więź, no. 1: $50-61$.

11. DZIERŻANOWSKI, JÓZEF. 1938. Ustawa o spółdzielniach. Rozporządzenie o własności lokali. Warsaw: Księgarnia Wydawnictw Prawniczych Mariana Gintera. 
12. EMMONDS, WILLIAM and FRANK A. SCHMID. 1999. "Credit Unions and the Common Bond." Federal Reserve Bank of St. Louis Review 81, no. 5: 41 - 64.

13. FAJARDO, GEMMA, ANTONI FICI, HAGEN HENRY, DAVID HEIZ, DEOLINDA MEIRA, HANS-H. MÜNKER and IAN SNAITH. 2017. Principles of European Cooperative Law. Principles, Commentaries and National Reports, Cambridge - Antwerp - Portland: Intersentia.

14. FRIDMAN, GERALD HENRY LOUIS. 1967. „Freedom of Contract.” Ottawa Law Review 2:1: 1 - 22.

15. GROCHOWSKI, MATEUSZ. 2017. Skutki braku zachowania formy szczególnej oświadczenia woli. Warsaw: C.H. Beck.

16. GROCHOWSKI, MATEUSZ. 2018. Wymogi formalne w umowach konsumenckich. Warsaw: C.H. Beck.

17. GRZYBOWSKI, STEFAN. 1985. "Stosunek cywilnoprawny". In System prawa cywilnego. Część ogólna 1, edited by Stefan Grzybowski, 177 214. Wroclaw - Warsaw - Cracow - Lodz: Ossolineum.

18. GUINNANE, TIMOTHY W. and SUSAN MARTI'NEZ-RODRI'GUEZ. 2011. "Cooperatives Before Cooperative Law: Business Law and Cooperatives in Spain, 1869 - 1931." Revista de Historia Económica - Journal of Iberian and Latin American Economic History 29, no. 1: 67 - 93. https://doi. org/10.1017/S0212610911000012.

19. HAUSER, ROMAN. 2010. "Stosunek administracyjny". In System Prawa Administracyjnego. Instytucje prawa administracyjnego 1, edited by Roman Hauser, Zygmunt Niewiadomski, Andrzej Wróbel, 193 - 212. Warsaw: C.H. Beck.

20. HENRY, HAGEN. 2012. Guidelines for Cooperative Legislation. Geneva: International Labour Organization.

21. INTERNATIONAL COOPERATIVE ALLIANCE. 2019. "Rules and by-laws". Accessed August 31, 2019. https://www.ica.coop/en/about-us/our-structure/alliance-rules-and-laws.

22. JEDLIŃSKI, ADAM. 2002. Członkostwo w spółdzielczej kasie oszczędnościowo - kredytowej. Warsaw: Wydawnictwo prawnicze LexisNexis.

23. JEDLIŃSKI, ADAM. 2014. "Perspektywy rozwoju prawa spółdzielczego." Zeszyty Senackie, no. 22: 9 - 19.

24. KOBER, ROUVEN. 2010. "Das „investierende Mitglied” - Wer und vor allem was steckt dahinter?." Zeitschrift für das gesamte Genossenschaftswesen 60, no. 1: 37 - 49. https://doi.org/10.1515/zfgg-2010-0105

25. KORNILAKIS, ANGELOS. 2017. "Report form Greece: The New Law on Social Enterprises in Greece." European Company Law Journal 14, no. 5: $206-210$.

26. KURIMOTO, AKIRA, JEAN-FRANCOIS DRAPERI, JEAN-LUIS BANCEL, SONJA NOVKOVIC, MERVYN WILSON, LINDA SHAW, EMILY LIPPOLD CHENEY AND DANTE CRACOGNA. 2015. Guidance Notes to the Co - operative Principles, Brussels: International Cooperative Alliance.

27. MIĆOVIĆ, MIODRAG. 2017. "The Legal Nature and the Framework for Cooperative Activities." Economics of Agriculture 64, no. 3: 1205 - 1218. https://doi.org/10.5937/ekoPolj1703205M 
28. Model Law for Credit Unions. 2015. Madison, WI: World Council of Credit Unions.

29. MÜNKER, HANS-H. 2016. Ten Lectures on Cooperative Law. Zurich: LIT Verlag.

30. PAPADOPOULOS, THOMAS. 2010. EU Law and the Harmonization of Takeovers in the Internal Market. Alphen aan den Rijn: Kluwer Law International.

31. PEEL, EDWIN and G. H. TREITEL. 2007. The Law of Contract. London: Sweet \& Maxwell.

32. PIETRZYKOWSKI, KRZYSZTOF. 1990. Powstanie i ustanie stosunku członkostwa w spółdzielni, Warsaw: Wydawnictwo Uniwersytetu Warszawskiego.

33. PIETRZYKOWSKI, KRZYSZTOF. 2012. "Prawa rzeczowe do lokali w spółdzielni mieszkaniowej". In System Prawa Prywatnego. Prawo rzeczowe 4, edited by Edward Gniewek, 269 - 458. Warsaw: C.H. Beck.

34. RADWAŃSKI, ZBIGNIEW. 1977. Teoria umów. Warsaw: Państwowe Wydawnictwo Naukowe.

35. SAFJAN, MAREK. 2012. "Pojęcie i systematyka prawa prywatnego". In System Prawa Prywatnego. Prawo cywilne - część ogólna 1, edited by Marek Safjan, 31 - 76. Warsaw: C.H. Beck.

36. SHAFFER, JACK. 1999. Historical Dictionary of the Cooperative Movement. Lanham, Maryland - Toronto - Plymouth, UK: The Scarecrow Press.

37. SKOCZEK, JACEK. 2013. Usługi płatnicze świadczone przez kasy oszczędnościowo - kredytowe. Zagadnienia cywilnoprawne. Sopot: Wydawnictwo Spółdzielczego Instytutu Naukowego.

38. STELMACHOWSKI, ANDRZEJ. 1998. Zarys teorii prawa cywilnego, Warsaw: Wydawnictwa prawnicze PWN.

39. SUCHOŃ, ANETA. 2015. "Wpływ polityki i prawa Unii Europejskiej na rozwój spółdzielni rolniczych w wybranych krajach członkowskich." Przegląd Prawa Rolnego, no. 1: 95 - 120. https://doi.org/10.14746/ ppr.2015.16.1.5.

40. SZUMAŃSKI, ANDRZEJ. 2008. "Spółdzielnia europejska z perspektywy polskiego prawa spółek." In Spółdzielnia europejska - szansa integracji i rozwoju spółdzielczości w Europie, edited by Adam Piechowski, 25 - 48. Warsaw: Krajowa Rada Spółdzielcza.

41. WORLD COUNCIL OF CREDIT UNIONS. 2013. "Statistical Report." Accessed August 29, 2019. https://www.woccu.org/documents/2013_Statistical_Report.

42. WORLD COUNCIL OF CREDIT UNIONS. 2017. "Statistical Report." Accessed August 29, 2019. https://www.woccu.org/documents/2017_Statistical_Report-Revised_Nov_2018.

43. WRZZOEK - ROMAŃCZÜK, MAŁGORZATA. 2003. "Rozporządzenie w sprawie statutu dla spółdzielni europejskiej (europejskiego zrzeszenia spółdzielczego). Council Regulation on the Statute for a European Cooperative Society - SCE." Zeszyty Naukowe Warszawiej Wyższej Szkoły Ekonomicznej, no. 27: $23-47$. 
44. ZAKRZEWSKI, PIOTR et. al. 2014. Spółdzielcze kasy oszczędnościowo kredytowe. Komentarz. Warsaw: C. H. Beck.

45. ZAKRZEWSKI, PIOTR. 2002. "Udział osób duchownych w tworzeniu spółdzielni w Wielkopolsce w XIX i w początkach XX wieku." Studia z prawa wyznaniowego 5: $155-170$.

46. ZAKRZEWSKI, PIOTR. 2018. "Legalna definicja spółdzielni". In Państwo - Konstytucja - Prawo. Księga pamiątkowa poświęcona Sędziemu Trybunału Konstytucyjnego Profesorowi Henrykowi Ciochowi, 525 - 547. Warsaw: Wydawnictwo Trybunału Konstytucyjnego.

47. ZALCEWICZ, ANNA. 2013. "Unie kredytowe w państwach Unii Europejskiej jako wyraz funkcjonowania społeczeństwa obywatelskiego - kazus polski, czyli o spółdzielczych kasach oszczędnościowo-kredytowych w świetle konstytucyjnej zasady społeczeństwa obywatelskiego." Europejski Przegląd Prawa i Stosunków Międzynarodowych, no. 1- 2: 33 - 45. 


\section{Derechos de autor}

El Boletín de la Asociación Internacional de Derecho Cooperativo es una revista de acceso abierto lo que significa que es de libre acceso en su integridad inmediatamente después de la publicación de cada número. Se permite su lectura, la búsqueda, descarga, distribución y reutilización legal en cualquier tipo de soporte sólo para fines no comerciales y según lo previsto por la ley; sin la previa autorización de la Editorial (Universidad de Deusto) o el autor, siempre que la obra original sea debidamente citada (número, año, páginas y DOI si procede) y cualquier cambio en el original esté claramente indicado.

\section{Copyright}

The International Association of Cooperative Law Journal is an Open Access journal which means that it is free for full and immediate access, reading, search, download, distribution, and lawful reuse in any medium only for non-commercial purposes, without prior permission from the Publisher or the author; provided the original work is properly cited and any changes to the original are clearly indicated. 